\title{
Formal and Informal Waste Collection in Chinese Cities
}

Meine Pieter van Dijk*

Professor, UNESCO-IHE Institute for Water Education, Netherlands

*Corresponding author: Meine Pieter van Dijk, Professor, UNESCO-IHE Institute for Water Education, Netherlands, Tel: +31152151779; E-mail:

m.vandijk@unescoihe.org

Received date: September 22, 2014; Accepted date: September 23, 2014; Published date: September 30, 2014

Copyright: (c) 2014 van Dijk MP, et al. This is an open-access article distributed under the terms of the Creative Commons Attribution License, which permits unrestricted use, distribution, and reproduction in any medium, provided the original author and source are credited.

\section{Editorial}

China is the country where waste is usually reduced, often reused and certainly recycled. However, this is not only because of the formal sector, but rather because of the informal sector operators.

There were times that empty containers returning from Europe after bringing Chinese industrial products were filled with waste to be recycled in China, but since the incinerators in my country (the Netherlands) do not have enough waste to burn we are more reluctant to export waste. Recently we even imported waste from Italy to keep the fires going!

The problem in the Netherlands is that people prefer separating waste and dispose separately of their paper, plastic, compostable, small chemical, garden and other waste. Hence the regular bin is not as full any more as before. They have been educated for year to do so and there are incentives, like paying less tax for a small municipal waste basket.

In China you can find waste baskets with two, three or four compartments. The essential distinction is between recyclable and other waste (non recyclable). However, one also finds in the same city baskets with four compartments, with the headings paper, plastic, cans and others. Plus I found one with three options paper, plastic and others. I must admit I found it confusing, but I am not the only one. Looking deeper into the baskets, I found plastic both in the recyclable and other waste basket. Hence also the Chinese population in Beijing has a problem knowing what is exactly recyclable and what not.
Sustainability of urban solid waste collection is high on the agenda of city managers. They are often saved by the informals. I have this fantastic picture where there is a niece reserved place for the waste of the neighbourhood with a wall all around it. The inhabitants do not have to sort it out, because the place is regularly emptied by the municipality. However, the next morning I found the whole content of the walled waste castle just dumped outside the walls. An informal operator had taken out everything one by one and sorted it. He knew what is recyclable, which he would take with him and what not, which he left behind as 'other waste'.

What can we learn from this? One that designing a system without properly informing the population does not work. The German put big stickers on differently coloured waste baskets explaining exactly what should go into it. Secondly, we may design a formal system, but tend to forget that waste is also an asset for the poor. They will do the selection and take out the valuable waste to make some money. Finally, if we study waste collection systems it is not enough to look at the formal system. In many countries the informal sector part is as important and needs to be considered and involved in planned changes! It strikes that when looking at recent papers on solid waste collection very few look at this informal part of the system, while they are often part of an integrated value chain, going from the waste collection to the sorting and from trying to reuse products to recycling the relevant components. Everything we want and at very low cost. 